\title{
Obitelj u fokusu najčitanijeg hrvatskog tiska
}

\author{
Ana Volarić Mršić*, Filip Kopanica**
}

\begin{abstract}
Sažetak
Obitelj je čuvarica života, ljubavi i kulture jednog naroda, najvećih vrijednosti ljudskog društva. S ciljem otkrivanja sadržaja koji o obitelji objavljuje najčitaniji hrvatski tisak, analizom su obuhvaćeni Večernji list, Jutarnji list i 24 sata od 15. svibnja 2015. do 31. prosinca 2017. godine. Odabrani su oni napisi koji su se bavili temom obitelji, što je bilo istaknuto u naslovu i podnaslovu, kao $i$ u sadržaju. Analiza odabranih napisa sastojala se u tome da se na već pripremljena pitanja analitičke matrice unose odgovori, koji su na kraju prikazani u brojčanom obliku, a odnosili su se na deontološke standarde, kao što je ime autora objavljenih napisa, objektivnost, nepristranost $i$ istinitost, te u procjeni koji je povod i cilj objavljivanja tog napisa (informirati ili nešto drugo), koje se vrijednosti promiču sadržajem objavljenog napisa (tradicionalne ili nešto drugo), te koji se izvori podataka navode u analiziranom napisu. Rezultati su pokazali da hrvatske najčitanije novine o obitelji pišu pretežito radi informiranja, ali i zagovaranja određenih političkih procesa, a udio je senzacionalističkih napisa kada se piše o obitelji $24 \%$ ukupnog broja analiziranih napisa. Nadalje, tema o obitelji nije dublje obrađena od stane autora u hrvatskom najčitanijem tisku u $20 \%$ analiziranih napisa, a autori se rijetko referiraju na stručnjake iz područja prava, medicine, psihologije ili sociologije u manje od jedan posto analiziranih napisa. Paralelnom usporedbom dobivenih rezultata, u analiziranom periodu najviše je priloga objavio Večernji list (156), zatim Jutarnji list (128) te potom 24 sata (50), što je ukupno 337 priloga o obitelji.
\end{abstract}

Ključne riječi: obitelj, brak, Večernji list, Jutarnji list, 24 sata

Uvod

Granice svih dosadašnjih definicija obitelji, uvelike su se pomaknule. Unatoč nastojanjima svih progresivnih snaga koje se doslovno bore za (re)definiciju bra-

* Dr. sc. Ana Volarić Mršić, poslijedoktorandica na Hrvatskim studijima Sveučilišta u Zagrebu. Adresa: Borongajska cesta 83d, 10000 Zagreb, Hrvatska. E-adresa: avmrsic@gmail.com

** Filip Kopanica, mag. comm. i mag. educ. croat. Adresa: Vidikovac 21, 51500 Krk, Hrvatska. E-adresa: fkopanica@gmail.com 
ka i obitelji, činjenice iz svakodnevnog života govore u prilog fokusiranih i tromih društvenih struktura, koje suvremeno društvo neusiljeno vode naprijed, malim svakidašnjim, neprimjetnim i tihim koracima. Nevladine udruge i ostali građani posvetili su veliku pozornost prijedlogu novog Obiteljskog zakona, za koji je najavljeno da neće sadržavati definiciju obitelji. To je samo jedan od mnoštva fenomena čiji smo svjedoci u suvremenom hrvatskom društvu, za koje se u jednom istraživanju tvrdi: „Suvremeno hrvatsko društvo upravo karakteriziraju izrazite promjene na svim područjima društvenog života, od obitelji, kulture, religije do politike, ekonomije, obrazovanja itd. Očekivano, jedna od ključnih karakteristika tih promjena jest sučeljavanje modernizacije i tradicije, koje zbog niza kako 'objektivnih' tako i 'subjektivnih' društveno-povijesnih razloga otvara prostor raznim devijacijama, koje pak pridonose općem stanju anomije“ (Nikodem et al., 2010, 627).

U tom društvenom procesu, mediji imaju posebnu ulogu u senzibiliziranju javnosti za važnu temu kao što je obitelj. Ovom se analizom pokušalo procijeniti koliko se medijske pozornosti pridaje obitelji i obiteljskim temama, koje su glavne poruke koje naš najčitaniji tisak šalje čitateljskoj javnosti kada govori o obitelji, te poštuju li se deontološki standardi dobre novinarske prakse u analiziranim napisima.

Prvi dio ovog članka sadržava kratki pregled važećeg hrvatskog obiteljskog zakona s definicijom braka i obitelji. U drugom dijelu članka predočeni su rezultati analize odabranih napisa prema kriteriju glavne teme o obitelji, uz prilagođeni tablični prikaz numeričkih rezultata, a u trećem se dijelu donosi zaključak na temelju dobivenih rezultata analize sadržaja napisa u kojima je glavna tema bila obitelj.

\section{Pojam i obilježja bračnog i obiteljskog prava}

\subsection{Pojam i obilježja bračnog prava}

Brak je društveni odnos koji se tijekom vremena transformirao u pravno uređen odnos i poseban obiteljskopravni institut. Temeljne predodžbe o braku povezuju se s nekoliko njegovih bitnih obilježja, od kojih je na prvom mjestu načelo pristanka na brak slobodnom odlukom žene i muškarca. Brak je monogaman s obzirom na to da se u kršćanskom kulturnom krugu brak shvaća kao duhovna i tjelesna životna zajednica (jedne) žene i (jednog) muškarca. Brak bi trebao biti doživotan, no načelna nerazrješivost ne znači (više) i apsolutnu nemogućnost raskida bračnog odnosa za života žene i muža (Alinčić et al., 2007, 21).

Dio obiteljskog prava sadržava norme koje braku kao društvenomu odnosu daju obilježja i značenje obiteljskopravnog instituta. Teorijske definicije braka u izvorima rimskog prava ističu moralnu i etičku stranu braka, što je tipičan sadržaj i način izražavanja institucionalnog shvaćanja braka. Prema Modestinovoj definiciji brak je zajednica muža i žene ujedinjenih za čitav život, ustanova božanskog i ljudskog prava, a prema Justinijanovoj: brak je zajednica muža i žene ustanovlje- 
na radi trajne životne zajednice (Alinčić et al., 2007, 22). Brak se kao institucija u suvremenom svijetu doživljava različito, što ovisi o pojedinoj zemlji.

\subsection{Ustavna definicija braka}

Ustavna definicija braka u članku 62. glasi: „Obitelj je pod osobitom zaštitom države. Brak je životna zajednica žene i muškarca. Brak i pravni odnosi u braku, izvanbračnoj zajednici i obitelji uređuju se zakonom“ (NN 56/1990).

Definicija braka u čl. 5 Obiteljskog zakona glasi: „Brak je zakonom uređena životna zajednica žene i muškarca“ (NN 103/2015).

Početak definicije, kako ističe Alinčić, upozorava da je brak zakonom uređena zajednica, što znači da se u pravnom sustavu brakom priznaje samo zajednica za koju su ispunjeni propisani zahtjevi. Te zahtjeve određuju pravila o sklapanju i prestanku braka, a zakonom su uređeni i pravni učinci braka (Alinčić et al., 2007, 24). Temeljni sadržaj bračnog odnosa proizlazi iz dijela definicije prema kojem je brak životna zajednica žene i muškarca. Institut braka je prema tome društveno i pravno namijenjen samo osobama koje su različitog spola. S tim u skladu propisane su pretpostavke za postojanje braka (Alinčić et al., 2007, 24). U sadržajnom pogledu, žena i muškarac u bračnoj životnoj zajednici zadovoljavaju različite osobne i zajedničke potrebe: osjećajne, seksualne, prokreativne, moralno-etičke, materijalne, kulturne i druge naravi. Zakon propisuje učinke braka, no samo kao okvirna pravila ponašanja, jer se pravnom normom ne može utjecati na zbiljsku kakvoću bračnog odnosa (Alinčić et al., 2007, 24).

Odredba je čl. 6 Obiteljskog zakona da se brak sklapa „suglasnom izjavom žene i muškarca u građanskom ili vjerskom obliku“ (NN 103/2015). Normom je ozakonjeno pravo na izbor oblika u kojem se brak može sklopiti. Osim toga, u normi su sadržana i tri načelna zahtjeva za uspostavu braka. To su: načelo konsenzusa jer se traži suglasna izjava o braku, načelo heteroseksualnosti jer brak sklapaju žena i muškarac, te načelo monogamnosti jer su osobe koje sklapaju brak imenovane u jednini (Alinčić et al., 2007, 25).

\subsection{Definicija obitelji}

Do danas je ponuđeno mnogo definicija obitelji s obzirom da se njome bave brojna znanstvena i stručna područja, kao i brojni autori kroz stoljeća. Neke definicije prihvaćene su kao osnovno gledište pojedinih znanstvenih područja, primjerice sociološka definicija: obitelj je osnovna jedinica društva; psihološka: obitelj je bitan faktor primarne socijalizacije i uopće psihičkog razvoja djeteta, pravna definicija: obitelj je skup osoba povezanih brakom (ili vanbračnom zajednicom) i srodstvom, između kojih postoje zakonom utvrđena prava i dužnosti (Alinčić et al., 1999, 23). Iz tih definicija vidljivo je da su pokušaji tumačenja pojma obitelji vrlo općeniti i daju tek neke osnovne naznake određenja ove društvene skupine. Svojom univerzalnom raširenošću u ljudskom društvu, raznolikošću strukture, odnosa, definicije sadrže nevjerojatno mnogo kombinacija pojavnosti tako da bi se moglo reći da je svaka obitelj jedinstvena i da bi, u skladu s postavkama post- 
moderne, ali i suvremenog shvaćanja prakse socijalnog rada s obitelji, zahtjeva struke i iskustva stručnjaka u radu s obitelji za svaku od njih trebalo sačiniti posebnu definiciju (Janković, 2008, 18).

Ovako je obitelj definirao sveti Ivan Pavao II.:

»Obitelj, zasnovana i oživotvorena ljubavlju, jest zajednica osoba: bračnih drugova, muža i žene, roditelja i djece, rodbine. Njezina prva zadaća jest vjerno živjeti stvarnost zajedništva u trajnom naporu da se promiče istinita zajednica osoba. Nutarnje počelo, trajna snaga i konačan cilj takvog zadatka jest ljubav: kao što bez ljubavi obitelj nije zajednica osoba, tako bez ljubavi obitelj ne može živjeti, rasti niti se usavršavati kao zajednica osoba. Ono što sam napisao u enciklici Redemptor hominis, svoju izvornu i povlaštenu primjenu nalazi ponajprije u obitelji kao takvoj: 'Čovjek ne može živjeti bez ljubavi. Sam po sebi on ostaje neshvatljivo biće, život mu je lišen smisla ako mu se ne objavi ljubav, ako se ne sretne s ljubavlju, ako je ne iskusi i ne usvoji, ako u njoj živo ne sudjeluje.' Ljubav između muža i žene u braku, pa prema tome u širem smislu i ljubav između članova iste obitelji - između roditelja i djece, između braće i sestara, između rodbine i ukućana - prožeta je i podržavana neprestanim unutrašnjim dinamizmom, koji obitelj vodi k uvijek sve dubljem i prisnijem zajedništvu, što je temelj i duša bračne i obiteljske zajednice « (FC 18).

Tako u samom uvodu Obiteljskog zakona piše: »Ovim se Zakonom uređuju brak, izvanbračna zajednica žene i muškarca, odnosi roditelja i djece, mjere za zaštitu prava i dobrobiti djeteta, posvojenje, skrbništvo, uzdržavanje, obvezno savjetovanje i obiteljska medijacija te postupci u vezi s obiteljskim odnosima i skrbništvom« (NN 103/2015). Svaka je država vrlo zainteresirana uređivati međuljudske odnose te jamčiti građanima prava i podsjećati na dužnosti svojih građana koji su vezani krvnim srodstvom, ili drugim odnosima.

Kroz prizmu tih obiteljskih teorija i važećih hrvatskih zakona sada možemo analizirati napise o obitelji koji su se u hrvatskim medijima pojavljivali tijekom 2015., 2016. i 2017. godine radi dobivanja podataka o tome koji je glavni motiv objavljivanja napisa o obitelji u analiziranom tisku, koji su izvori na kojima se informacije temelje, uključuju li se stručne osobe radi iznošenja stručnog mišljenja kada se govori o obitelji i obiteljskim odnosima, koliko su aktualna politička zbivanja prisutna u analiziranim napisima i u kojem smjeru ide senzibilizacija javnosti putem najčitanijih novina u Hrvatskoj (za tradicionalne vrijednosti ili nešto drugo).

\section{Analiza objavljenih napisa o obitelji}

\subsection{Metodologija analize}

Ovom analizom obuhvaćeno je vremensko razdoblje od svibnja 2015. do kraja 2017. godine. Vremensko razdoblje odabrano je s obzirom na frekvenciju objavljivanja napisa o obitelji, koji se od svibnja 2015. češće objavljuju. Polazišna je hipoteza procjena objektivnosti i sveobuhvatnosti sadržaja kojim se informira 
javnost, kada se govori o obitelji, u što bi trebali biti uključeni i stručnjaci. Uz to, dodatna je hipoteza da naš dnevni tisak pod pojmom obitelji podrazumijeva tradicionalnu obitelj (otac, majka, djeca i rodbina), u skladu s Obiteljskim zakonom i stavovima velike većine građana, što proizlazi iz rezultata društvenih istraživanja koja se redovito provode u Hrvatskoj.

Analiziran je sadržaj objavljenih napisa najčitanijih hrvatskih tiskanih novina Jutarnji list, Večernji list i 24 sata. Kriterij prema kojem su objavljeni tekstovi ušli $\mathrm{u}$ analizirani uzorak njihova je glavna tema - obitelj o kojoj se u napisu govori, počevši od naslova, podnaslova i samog teksta, kako to u metodološkom smislu navode stručnjaci (Mejovšek, 2005, 23).

Metoda analize sadržaja korištena za donošenje zaključaka je kvalitativna (vrsta priloga, vrste i broj izvora informacije, objektivnost, istinitost, odnos teksta i grafičke opreme, nepristranost, mišljenje stručnjaka, novinarska deontologija) i kvantitativna (broj kategoriziranih napisa prema sadržaju, udio kategoriziranih napisa u cjelokupnom broju prikupljenih napisa iskazano u relativnim brojevima) (Bickman i Rog, 1998, 261).

Postupak klasificiranja napisa u odnosu prema tradicionalnim obiteljskim vrijednostima temelji se na pojmovima koji afirmiraju ili negiraju tradicionalne obiteljske vrijednosti (tradicionalnu obitelj). Pod tradicionalnim obiteljskim vrijednostima u ovoj analizi podrazumijeva se heteroseksualna bračna ljubav, vjernost, odgovorno roditeljstvo, skrb, obiteljska solidarnost, supsidijarnost, sebedarje, vjera, domoljublje.

Zbirni rezultati analize prikazani su u tablici, iz čega je vidljivo da je od 15. svibnja 2015. godine do kraja 2017. objavljeno ukupno 337 priloga obiteljske tematike u Večernjem listu, Jutarnjem listu i 24 sata.

\subsection{Rezultati analize}

Tablica 1. Rezultati analize objavljenih napisa - izdvojena pitanja Figure 1. Results of the analysis of published articles — selected questions

\begin{tabular}{|l|c|c|}
\hline Broj napisa o obitelji & $\mathrm{N}=337$ & $100 \%$ \\
\hline Večernji list & 156 & 46 \\
\hline Jutarnji list & 128 & 38 \\
\hline 24 sata & 50 & 16 \\
\hline Prevladavajući položaj napisa & Str. 1.-10. & $\%$ \\
\hline Večernji list & 57 & 37 \\
\hline Jutarnji list & 22 & 17 \\
\hline 24 sata & 21 & 42 \\
\hline Prevladavajuća vrsta napisa & & $\%$ \\
\hline Večernji list: Proširena vijest & 80 & 51 \\
\hline Jutarnji list: Vijest & 67 & 52 \\
\hline 24 sata: Vijest & 38 & 76 \\
\hline
\end{tabular}




\begin{tabular}{|c|c|c|}
\hline Prevladava povod pisanja napisa & & $\%$ \\
\hline Večernji list: informirati & 148 od 156 & 95 \\
\hline Jutarnji list: informirati/zagovarati & 97 od 128 & 76 \\
\hline 24 sata: senzacionalizam & 41 od 50 & 82 \\
\hline Prilog se odnosi na tradicionalnu obitelj & & $\%$ \\
\hline Večernji list & 152 od 156 & 97 \\
\hline Jutarnji list & 119 od 128 & 93 \\
\hline 24 sata & 45 od 50 & 90 \\
\hline Autor napisa: novinar & & $\%$ \\
\hline Večernji list & 153 od 156 & 98 \\
\hline Jutarnji list & 125 od 128 & 97 \\
\hline 24 sata & 32 od 50 & 64 \\
\hline Napis odražava osobni stav autora & & $\%$ \\
\hline Večernji list & 95 od 156 & 61 \\
\hline Jutarnji list & 119 od 126 & 94 \\
\hline 24 sata & 45 od 50 & 90 \\
\hline Citiranje stručnjaka u napisu & & $\%$ \\
\hline Večernji list & 15 od 156 & 1 \\
\hline Jutarnji list & 8 od 128 & 0,6 \\
\hline 24 sata & 0 & 0 \\
\hline Afirmacija obiteljskih vrijednosti & & $\%$ \\
\hline Večernji list & 123 od 156 & 79 \\
\hline Jutarnji list & 101 od 128 & 84 \\
\hline 24 sata & 28 od 50 & 56 \\
\hline
\end{tabular}

Ciljanom analizom odabranih priloga utvrđeno je da je Večernji list više od polovice priloga obiteljske tematike objavio među prvih deset stranica, a Jutarnji list i 24 sata obiteljske teme pretežito su objavljivali poslije desete stranice. Vezano uz ovu analizu je i podatak da je vrsta priloga koja prevladava u Večernjem listu proširena vijest, a u Jutarnjem listu i 24 sata prevladava obična vijest, što navodi na zaključak da se nije dublje obrađivalo temu o obitelji, kako bi se čitateljima ponudilo neki širi okvir s ciljem donošenja vlastitih sudova, kako to preporuča novinarska etika (Belsey i Cadwick, 1996, 158-180).

Analiza je nadalje pokazala da je većina objavljenih priloga obiteljske tematike u Večernjem listu informativnog karaktera, a za Jutarnji list prevladavajući je cilj, sa skoro $80 \%$, bio uz informiranje također i zagovaranje određenih interesa, osobito političkih. Primjerice, za aktivnosti ili protiv aktivnosti određenih nevla- 
dinih udruga, što se prepoznaje po karakteristikama naslova i podnaslova napisa, vrsti postavljenih pitanja sugovornicima i načinu zaključivanja napisa. Također je uočen velik broj napisa u kojima se iznose afirmativni stavovi za određene političke programe, ili u kojima se prepoznaje pripremanje izborne kampanje određenih stranaka, iz čega je moguće polučiti zaključak da je cilj objavljivanja napisa promicanje ideja i stavova određenih interesnih skupina, koristeći obiteljske teme kao povod. Tabloid 24 sata u analiziranom periodu objavio je $82 \%$ priloga senzacionalističkoga karaktera, koristeći obiteljske tragedije kao priliku za privlačenje pažnje čitatelja. Također je karakteristika analiziranih priloga i redovito objavljivanje fotografija koje dominiraju u odnosu na tekst i u kojima se osobe o kojima se piše bezpridržajno vizualno izlažu javnosti, kao i njihova djeca, čime se često krši pravo na privatnost (Belsey i Cadwick, 1996, 114-119).

$\mathrm{U}$ analiziranim se napisima govorilo o tradicionalnoj obitelji, i to u sva tri dnevna lista uz stopu od $90 \%$, što upućuje na zaključak da su prilozi u kojima dominira tema o primjerice istospolnim brakovima ili obiteljima (kada se govori o događajima izvan Hrvatske) zapravo rijetkost u našem najčitanijem dnevnom tisku. Autor objavljenih priloga obiteljske tematike je u preko $90 \%$ novinar za Večernji list i Jutarnji list, a u skoro $40 \%$ to je bila agencijska vijest ili nepotpisani prilog nepoznatog autora u tabloidu 24 sata.

Analizom je utvrđeno da u Jutarnjem listu i 24 sata osobni stav autora prevladava u preko $90 \%$ objavljenih priloga u kojima se govori o obitelji, a u Večernjem listu taj je trend zamijećen u $61 \%$ objavljenih napisa. Važan je podatak i taj koji otkriva da je u svega nekoliko objavljenih tekstova prisutno mišljenje stručnjaka (sociologa, psihologa, liječnika, pravnika i sl.) kada se govori o obitelji, odnosno, govoreći u postotcima, to iznosi manje od $1 \%$ svih objavljenih napisa. Iz toga se podatka može zaključiti da politika uredništva ne vodi dovoljno računa o mišljenju struke kada se govori o obitelji. U velikom broju prevladavaju, kako je to već rečeno, vijesti, uz koje nema popratnog komentara stručnjaka, kad je riječ o nasilju u obitelji, nekom specifičnom obiteljskom događaju, za koji bi komentar stručnjaka bio vrlo koristan.

Tražeći podatak o tome koje se vrijednosti promiču objavljenim napisima o obitelji, moglo bi se zaključiti da je prisutan relativno visok postotak onih napisa u kojima se spominju tradicionalne obiteljske vrijednosti, kao primjerice ljubav između muža i žene, skladan odnos, briga oko odgoja djece, vjernost, domoljublje i sl. To je potvrdilo i posebno istraživanje tijekom 2014. godine o zastupljenosti bioetičkih tema u hrvatskom tisku, iz kojega proizlazi da su u Večernjem listu, Jutarnjem listu i 24 sata obiteljske teme na četvrtom mjestu po zastupljenosti od ukupno 39 bioetičkih tema (Volarić Mršić, 2017, 68). Međutim, kada se pitanje postavi obrnuto, tj. koliko je članaka objavljeno, a u kojima se direktno ili indirektno promiču neke druge vrijednosti koje se pokušava prikazati kao obiteljske, to u brojkama izgleda ovako: u Večernjem listu 33 priloga, u Jutarnjem listu 27, te u 24 sata 22 priloga u vremenskom razdoblju od svibnja 2015. do kraja 2017. godine. Povod je uglavnom neka međunarodna vijest, aktualna politička zbivanja 
ili manifestacije kojima su za cilj promicanje nekih od građanskih prava, od čega je velik broj napisa smješten u rubriku Obitelj i Lifestyle.

Kao što proizlazi iz ove analize, rijetko se nađu napisi u tisku koji bi sadržavali konkretne savjete i pohvalne primjere uspješnog obiteljskog života, jer to i nisu senzacionalne vijesti koje povećavaju čitanost. Također je primjetan otpor kada treba pratiti događaje i inicijative građana koji promiču tradicionalne obiteljske vrijednosti, što se vidi po poziciji i opsegu napisa koji se objavljuju o tome u najčitanijem hrvatskom tisku. Ponekad ti događaji, društveno važni, nisu uopće medijski popraćeni.

\subsection{Usporedba s nekim inozemnim i hrvatskim istraživanjima}

Analiza sadržaja tiska, kojemu je cilj procjena kvalitete istih, prema deontološkim kriterijima novinarstva, vezano uz temu tradicionalne obitelji i njezinih vrijednosti, prava je rijetkost kako u Hrvatskoj, tako i u svijetu. Istraživanja se uglavnom odnose na relaciju i utjecaj tiska, a osobito novih medija na obitelj i pojedince. Uz tu kategoriju znanstvenog istraživanja treba spomenuti studiju objavljenu u Njemačkoj kojom se željelo procijeniti kako rod utječe na postupke diskursa u vezi sa sadržajem obiteljske tematike. Analizirani su tiskani njemački mediji tijekom 2011. i 2012. godine (Tank i Prinzing, 2014). To je istraživanje pokazalo da tekstove o obitelji pišu uglavnom novinarke, a slično kao i muškarci, kada se piše o obitelji, pozivaju se na tradicionalnu obitelj, unatoč činjenici da su razni alternativni oblici obiteljskog života sada društvena realnost. Također, to je istraživanje pokazalo da je obitelj, prema analizi tiskanih medija u Njemačkoj, na posljednjem mjestu interesa njihove politike. U zaključku, autorice primjećuju da se o obitelji treba pisati kao o društvenom subjektu, a ne ostatku društvenog konstrukta, da treba pokušati premostiti jaz između društvene stvarnosti i medijskih trendova kada je riječ o obitelji, te da bi se obiteljske udruge trebale potruditi senzibilizirati medijske urednike, kako bi se u medijima govorilo o akcijama, temama, vijestima i argumentima "u prilog obitelji”. Obraćaju se također i novinarima, pozivajući ih da ne prenose svoje subjektivne stavove kada pišu o obitelji, te da prenose i one činjenice koje su u suprotnosti s njihovim osobnim uvjerenjima, glede obitelji. Pozivaju i znanstvenike da više pažnje posvete istraživanju odnosa mas medija i obitelji (Tank i Prinzing, 2014, 112-114).

U Hrvatskoj je objavljeno nekoliko istraživanja vezano uz temu medijskog prikaza obitelji, osobito na Odsjeku za komunikologiju na Hrvatskim studijima Sveučilišta u Zagrebu (Vrhovski-Peran, 2012; Kopanica, 2014; Obad, 2016; Peran i Raguž, 2017). Tako u svojem istraživanju Vrhovski-Peran zaključuje da mediji o obitelji izvještavaju incidentno i senzacionalistički s ciljem podizanja naklade odnosno gledanosti, te da u napisima hrvatskog tiska obitelj najčešće biva temom u slučaju nekog incidenta ili problema (Vrhovski-Peran, 2012, 194). Vrijedi spomenuti da se priličan broj studenata Odsjeka za komunikologiju $\mathrm{Hr}$ vatskih studija Sveučilišta u Zagrebu odlučuje posvetiti toj vrsti analize tiska, elektroničkih medija i TV sadržaja u kojima se odabire neka specifična (bioetička) tema kao što je obitelj i njoj srodne teme (prava djece, palijativna skrb, 
prava žene, ovisnost, prava osoba s invaliditetom i druge), kako bi se dobila slika o tome koju poruku mediji šalju javnosti kada pišu o spomenutim temama. Tako Obad u svojem zaključku analize prikaza obitelji u hrvatskom tisku navodi: „Pokušavaju li mediji prirodni oblik obitelji svesti na 'stereotip'? Čovječanstvo, kao da je jedva čekalo da se prirodni oblik obitelji ukine kao društveno poželjna kategorija današnjice. Upravo se to može zaključiti analizom rezultata istraživanja, ali zanimljivo je da više od $90 \%$ čovječanstva živi u monogamnoj obitelji. Unatoč utjecaju medijskog sadržaja, koji svakodnevno površno i nestručno izvještava o obiteljskim pitanjima, stvarnost je potpuno drugačija. Zajednica muškarca i žene je prirodni, spontani oblik provođenja života na zemlji“ (Obad, 2016, 53).

\section{Zaključak}

Istraživanje kojemu je cilj bio utvrditi sadržajni profil napisa u kojima se govori o obitelji, i to u najčitanijem hrvatskom tisku, Večernjem listu, Jutarnjem listu i tabloidu 24 sata, pokazalo je da je u razdoblju od 15. svibnja 2015. do 31. prosinca 2017. objavljeno ukupno 337 napisa (članaka) kojima je glavna tema obitelj. Najviše je napisa objavio Večernji list (156) te nešto manje Jutarnji list (128), a tabloid 24 sata objavio je najmanje (50).

Odgovor na polazišnu hipotezu je, na temelju dobivenih rezultata, negativan, što znači da informacije koje govore o obitelji u najčitanijem hrvatskom tisku nisu cjelovite i objektivne, te da ti napisi uglavnom ne sadrže izjave i mišljenja stručnjaka. Od ukupno 337 analiziranih napisa, citiranje mišljenja stručnjaka prisutno je u svega 23 napisa, što iznosi manje od jedan posto.

Odgovor na dodatnu hipotezu da se sadržaj napisa u kojima se govori o obitelji odnosi na tradicionalnu obitelj, je potvrdan, s obzirom da je preko $50 \%$ analiziranih napisa posvećeno tradicionalnoj obitelji. Međutim, analizirani napisi koji su kategorizirani kao obiteljska tematika svojim sadržajem ne afirmiraju isključivo tradicionalne obiteljske vrijednosti, osobito ako je riječ o izvještavanju o obiteljskim nesrećama, naglašavajući senzacionalistički pristup događaju, ili jednostranost u odnosu na žrtvu ili krivca. Također, vijesti u kojima se govori o posvajanju ili odgoju djece od strane istospolnih parova, objavljuju se u rubrici Obitelj i Lifestyle, što negira tvrdnju te hipoteze.

Obiteljske teme smještene su među prvih deset stranica analiziranih dnevnih novina, i to pretežno u obliku vijesti, s razlikom Večernjeg lista, koji polovicu svojih napisa donosi u obliku proširene vijesti. Naši analizirani dnevni listovi pretežito govore afirmativno o tradicionalnim obiteljskim vrijednostima, uz to se povremeno pojavljuju uglavnom međunarodne vijesti u kojima se informira o događajima, sudskim procesima ili političkim pobjedama manjinskih društvenih grupa koje se trude neutralizirati, kako kažu, društvene i obiteljske stereotipe. Ti napisi, premda rijetki, dobivaju istaknuta mjesta i naslove u našem najčitanijem dnevnom tisku. Zanimljivo je da je upravo obrazovna reforma pokrenula niz reakcija građana, koji uviđaju da država pokušava preuzeti ulogu (pre)odgajatelja djece i mladih putem javnih ustanova. Masovni mediji u tome indirektno i di- 
rektno zagovaraju taj vid direktne povrede obiteljskih prava građana, a koja su im zajamčena Ustavom i Obiteljskim zakonom, što je vidljivo iz činjenice da se rijetko u analiziranim medijima pojavljuju predstavnici udruga i građana koji se zalažu za pravo na odgoj vlastite djece u skladu s vrijednostima svojih roditelja. Ako ih se medijski poprati, pokušava ih se utjecajno marginalizirati. Tako valjani argumenti za i protiv nisu proporcionalno zastupljeni u našem najčitanijem dnevnom tisku, što predstavlja kršenje dobre novinarske prakse (Malović et al., 2007, 23).

Cilj objavljivanja analiziranih priloga obiteljske tematike, slijedom ovog istraživanja u velikom je postotku prije svega informiranje (više od $70 \%$ napisa), a senzacionalizam je prisutan u najčitanijem hrvatskom tabloidu 24 sata na račun tuđih obiteljskih nesreća, što je redovito popraćeno i fotografijama mjesta i osoba. Iznadprosječan broj analiziranih napisa odražava osobni stav autora teksta, što je u neskladu s načelom neutralnosti u izvještavanju, temelju dobre novinarske prakse. Taj je stav eksplicitno ili implicitno iznesen u zaključku napisa. Rijetko se citiraju stručnjaci koji svakodnevno rade s obiteljima, kao socijalni radnici, pravnici, psiholozi ili liječnici (u manje od $1 \%$ napisa), a ako se netko i pojavljuje kao stručnjak, nerijetko je to i radi prikrivenog oglašavanja nekog proizvoda ili privatne prakse dotičnog stručnjaka.

Analiza sama po sebi ne znači mnogo ako ne postoje već spremne poluge od strane društva i pojedinaca kako bi se ojačalo obitelj. Mediji u tome ne daju bitniju podršku, osim što redovito izvještavaju o činjeničnom stanju, bez opsežnije obrade teme i prenošenja mišljenja i savjeta stručnjaka (Volarić Mršić 2017a, 326).

U usporednom istraživanju vrijednosti u 32 europske zemlje, pa i u Hrvatskoj, utvrđeno je da je Hrvatska među zemljama u kojima ,je institucija braka i obitelji vrlo važna u osobnom životu za oko $98 \%$ ispitanika“" te se u visokom postotku ne slažu s tvrdnjom da obitelj i brak predstavljaju zastarjelu instituciju (Nikodem et al., 2010, 638). S obzirom na činjenicu da o obitelji ovisi budućnost svake nacije, svakovrsni gospodarski, demografski, društveni i duhovni napredak, uz veliku pozornost koju trenutačno u javnosti izaziva indeks demografskog kraha, od velike važnosti i vrijedan hvale bit će afirmativni pristup javnih medija u jačanju obitelji kao institucije koju treba podržati, upravo zato što je tako krhka i ranjiva, prema riječima pape Benedikta XVI, koji je novinarima napomenuo da »S obzirom na utjecaj koji imaju u javnosti, budu promicatelji dostojanstva obitelji, njezinih prava i obveza, ističući njezinu ljepotu« (Benedikt XVI., 2008, 1). Uz to, s obzirom na rezultate ovoga istraživanja, valjalo bi se pozvati i na tvrdnju da su obilježja svakog pravog profesionalca u medijima: poziv, akademsko obrazovanje, društveni nadzor, autonomija i odgovornost (Labaš, 2011, 193), te u sadašnjem povijesnom trenutku stavljanjem naglaska na odgovornost, koja svaki čimbenik društvenog života, a osobito novinare ili urednike postavlja na njihovo pravo mjesto, stavljajući u fokus istinu i opće dobro. 


\section{Literatura:}

Alinčić, Mira (1999). Komentar Obiteljskog zakona. Zagreb: Narodne novine.

Alinčić, Mira; Hrabar, Dubravka; Jakovac-Lozić Dijana; Korać-Graovac Aleksandra (2007). Obiteljsko pravo. Zagreb: Narodne novine.

Belsey, Andrew; Chadwick Ruth (1996). Etica e politica dell'informazione: la ricerca della qualità. u Belsey, Andrew; Chadwick Ruth (1996) (ur.). Etica e giornalismo. Torino: SEI. (3-23).

Benedikt XVI. (2008). I mezzi di comunicazione sociale: Al bivio tra protagonismo e servizio: Cercare la verità per condividerla. Cinisello Balsamo: Edizioni Paoline.

Bickman, Leonard; Rog, Debra (1998). Handbook of Applied Social Research Methods. Newsbury Park: Sage.

FC. Familiaris consortio. Ivan Pavao II., Familiaris consortio: Obiteljska zajednica: Apostolska pobudnica o zadaćama kršćanske obitelji u suvremenom svijetu. Zagreb: Kršćanska sadašnjost, 1997.

Janković, Josip (2008). Obitelj u fokusu. Zagreb: Knjižara Ljevak.

Kopanica, Filip (2015). Prikaz građanske inicijative U ime obitelji u hrvatskim medijima (Diplomski rad). Sveučilište u Zagrebu.

Labaš, Danijel (2011). Hrvatski novinari i mediji: od doba „beskućništva“ do „okućivanja“ u Labaš, Danijel (2011), (ur.), Komunikacija i mediji u krizi. Zagreb: Hrvatski studiji, (193-210).

Malović, Stjepan; Ricchiardi, Sherry; Vilović, Gordana (2007). Etika novinarstva. Zagreb: ICEJ.

Mejovšek, Milko (2005). Metode znanstvenog istraživanja u društvenim i humanističkim znanostima. Jastrebarsko: Naklada Slap.

Nikodem, Krunoslav; Aračić, Pero; Džinić, Ivo (2010). Važnost braka i obitelji u hrvatskom društvu: Analiza osnovnih pokazatelja u razdoblju od 1999. do 2008. godine. Bogoslovska smotra, 80(2), 623-642.

Obad, Mirela (2016). Prikaz obitelji u medijima (Diplomski rad). Sveučilište u Zagrebu.

Obiteljski zakon. Narodne novine, 103/2015.

Tank, Jennifer; Prinzing, Marlis (2014). Remnant "Family": The role of women in the media discourse on families. Essachess: Journal for Communication Studies, 7(2), 95-117.

Ustav Republike Hrvatske (2016), Zagreb: Školska knjiga.

Volarić Mršić, Ana, (2017). La bioetica e i mass media in Croazia. Zagreb: vlastita naklada.

Volarić Mršić, Ana, (2017a). Bioetika u hrvatskom dnevnom tisku, u Obnovljeni život. (72, 3/317-346).

Vrhovski-Peran, Suzana (2012). Slika obitelji u hrvatskim medijima: Mediji i katolički nauk o obitelji. Zagreb: Hrvatski studiji Sveučilišta u Zagrebu.

Vrhovski-Peran, Suzana Raguž, Anđelka (2017). Obitelj u medijima, mediji u obitelji: izazovi i poticaji. u Zaštita i promicanje dobrobiti djece, mladih i obitelji. Zagreb: HKS, (84-85). 
Focusing on the Family in the Top Croatian Newspapers

Ana Volarić Mršić*, Filip Kopanica**

Summary

The family is the keeper of life, love, the culture of a nation - the greatest values of human society. For analysis purposes, the most-read Croatian newpapers, Večernji list, Jutarnji list and 24 sata, issued between May 15, 2015 and December 31, 2017 were examined for content on the family. Articles stressing this topic in their title, subtitle and in their content were selected. Analysis consisted in entering responses to the questions on an analytical matrix prepared ahead of time. Responses presented in numerical form in the conclusion refer to deontological standards such as the name of the author of the published article, objectivity, unbiasedness and truthfulness. Analysis also involved an evaluation of the motive and goal of publishing the said article (to inform or otherwise) and the values promoted by means of the content of the published article (traditional or otherwise). Also, the information sources cited in the article were noted. Results indicate that the most-read Croatian newspapers write on the family mainly for the purpose of informing their readers but also for promoting certain political processes, while the proportion of sensationalistic articles on the family make up $24 \%$ of the total number of articles examined. Furthermore, the topic of the family is not deeply elaborated by those writing for top newspapers in $20 \%$ of the articles analysed, while writers rarely make references to experts in the fields of law, medicine, psychology or sociology, that is, in less than 1\% of the examined texts. Through parallel comparison of the results obtained during the specified time period, we find that most articles were published in Večernji list (156), followed by Jutarnji list (128), and 24 sata (50) which is a total of 337 articles dealing with the family.

Key words: family, marriage, Večernji list, Jutarnji list, 24 sata

* Ana Volarić Mršić, Ph.D., Post-Doctorand. Croatian Studies, University of Zagreb. Address: Borongajska cesta 83d, 10000 Zagreb, Croatia. E-mail: avmrsic@gmail.com

** Filip Kopanica, mag. comm. i mag. educ. croat. Address: Vidikovac 21, 51500 Krk, Croatia. E-mail: fkopanica@gmail.com 